FAYVISHENKO Diana - PhD in Economics, Associate Professor Department of Journalism and Advertising, Kyiv National University of Trade and Economics (fayvishenko.ds@gmail.com).

ФАЙВИШЕНКО Диана Сергеевна - кандидат экономических наук, доцент кафедры журналистики и рекламы, Киевский национальный торговоэкономический университет (ул. Киото, 19, г. Киев, 02000, fayvishenko.ds@gmail.com).

- ЗОВНІШНЬОЕКОНОМІЧНА ДІЯЛЬНІСТЬ, ТОВАРНІ ПОТОКИ СУБ'ЄКТІВ ГОСПОДАРЮВАННЯ ТА ЇХ ІНФРАСТРУКТУРНЕ ЗАБЕЗПЕЧЕННЯ

УДК: 332.3:504.03

DOI: $10.37128 / 2411-4413-2020-2-5$

ВПЛИВ ЦИФРОВОї

ЕКОНОМІКИ НА ГЛОБАЛІЗАЦІЮ
КОЛЯДЕНКО С. В., доктор економічних наук, професор кафедри комп'ютерних наук та економічної кібернетики, Вінницький національний аграрний університет (м. Вінниця)

У статті досліджено основні напрями та тенденції сучасної економіки (цифрової) та їі вплив на глобалізаційні процеси, щзо проходять у сучасних умовах. Зазначено, щзо цииррова економіка набула теперішнього визначення не так давно, пройшовши складний шлях становлення як у світі, так $і$ в Украӥні. Формуючись як сучасна наука, ичифрова економіка набуває рис сучасності: виникають та впроваджуються у наукову теорію нові терміни, категорії, поняття, інструментарій тощзо.

Термін «цифрова економіка», хоч і використовується досить давно в економічній спільноті світу, проте не всі ї̈ характеристики вже описані з погляду теоретичної економіки, а тим більше, ті специфічні терміни, що супроводжують ї̈ в економічних дослідженнях вчених.

Цифрову економіку визначає низка аспектів у технологічному, глобальному, діджиталізованому, соціальному напрямах. У нашій статті показано та обгрунтовано иляхи становлення деяких термінів, щуо використовуються в изьому напрямі та обтрунтовуються (в деяких випадках пропонується власні) формулювання таких термінів, шуо або використовуються в іншомовних джерелах, або прийшли з інших галузей. Передусім це технічні терміни, економічне обтрунтування яких необхідне для сучасної теоретичної думки.

Відтак, у статті запропоновані для використання в сучасній економічній науці деякі терміни, зокрема: ичифровий коворкінг-ичентр, крос-платформа з циифровою індустрією, 
циифровий хаб-студія, хаб-асоиіаџія, хакатон, Інтернет речей; тлумачення деяких із них запропоновано автором.

Досліджено сучасний вплив цифрової економіки на глобалізацію $і$ виявлено деякі тендениії та наслідки ц̧ього впливу, що позитивно можуть відобразитись на подальшому розвитку IT-індустрії в економічі світу та України, особливо в подальшому розвитку малих та середніх підприємств - бази розвитку економіки на найближчий період, враховуючи передбачуване наближення чергової хвилі економічної світової кризи.

Ключові слова: цифрова економіка, класична економіка, глобалізація, цифровізація, IT-технології, цифровий коворкінг-центр, крос-платформа з цифровою індустрією, цифровий хаб-студія, хаб-асоціація, хакатон, Інтернет речей.

Рис.: 1. Лит.: 19.

\title{
THE IMPACT OF THE DIGITAL ECONOMY ON GLOBALIZATION
}

\author{
KOLIADENKO Svitlana, \\ Doctor of Economic Sciences, Professor of the Department \\ of Computer Science and Economic Cybernetics \\ Vinnytsia National Agrarian University \\ (Vinnytsia)
}

The article explores the main directions and trends of the modern economy - digital and its impact on globalization processes taking place in the modern world. Digital economy entered the modern definition is not so long ago, having gone through the difficult path of becoming both in the world and in Ukraine. Forming as a modern science, digital economy is becoming a feature of modern times: new terms, categories, concepts, tools are emerging and being introduced into scientific modernity.

Some terms have been proposed for use in modern economic science, including: digital coworking center, cross-platform with digital industry, digital hub studio, hub association, hackathon, internet of things; some of them have been interpreted by the author. The contemporary impact of the digital economy on globalization has been investigated and some trends, implications, which can positively affect the further development of the IT industry in the economy of the world and Ukraine, especially the development of small and medium-sized enterprises basis of economic development for the coming period, especially as the next wave of the global economic crisis approaches.

Although the term "digital economy" has long been used in the economic community of the world, not all its characteristics have been described in terms of theoretical economics, and even more so, those specific terms that accompany it in the economic studies of scientists.

The digital economy is determined by a number of aspects in the technological, global, digitized, social fields. This article shows and substantiates ways to form some terms used in this direction and justifies (in some cases propose own) the formulation of terms that are either used in foreign-language sources or come from other fields, especially technical terms, economic substantiation of which is necessary for modern theoretical thought.

Key words: digital economy, classical economy, globalization, digitalization, IT technologies, digital co-working center, cross platform with digital industry, digital hub studio, hub association, hackathon, internet of things.

Fig.: 1. Lit.: 19.

\section{ВЛИЯНИЕ ЦИФРОВОЙ ЭКОНОМИКИ НА ГЛОБАЛИЗАЦИЮ}


EФM

http://efm.vsau.org/

\section{КОЛЯДЕНКО С. В., доктор экономических наук, профессор кафедры компютерных науки экономической кибернетики, Винницкий национальный аграрный университет} (2. Винница)

В статье исследованы основные направления и тендениии современной экономики циифровой и ее влияние на глобализационные прочессы, которые происходят в современных условиях. Отмечено, что цифровая экономика приобрела современное определение не так давно, пройдя сложный путь становления, как в мире, так и в Украине. Формулируясь как современная наука, цицрровая экономика приобретает черты современности: возникают и внедряются в научную современность новые терминь, категории, понятия, инструментарий u m.d.

Предложено для использования в современной экономической науке некоторые термины, в частности: цифрровой коворкинг-цеентр, кросс-платформа с изифровой индустрией, цифровой хаб-студия, хаб-ассочиачия, хакатон, Интернет вещей; определения некоторых из них предложено автором. некоторые тенденции и последствия этого влияния, что положительно могут повлиять в дальнейшем на развитие IT-индустрии в экономике мира и Украины, особенно развития малых и средних предприятий - базиса развития экономики на ближайший период, особенно при приближении очередной волны экономического мирового кризиса.

Так, в статье предложень для использования в современной экономической науке некоторые термины, в частности: изифровой коворкинг-иентр, кросс-платформа с ијифровой индустрией, иифровой хаб-студия, хаб-ассоииаџия, хакатон, Интернет вещей; толкование некоторых из них предложено автором.

Исследовано современное влияние ичифровой экономики на глобализаџию и выявлень некоторые тенденции и последствия этого воздействия, положительно могут сказаться на дальнейшем развитии ИТ-индустрии в экономике мира и Украины, особенно в дальнейшем развитии мальхх и средних предприятий - базиса развития экономики на ближайший период, учитывая предполагаемое приближения очередной волны экономического мирового кризиса.

Ключевые слова: цифровая экономика, классическая экономика, глобализация, цифровизация, ІТ-технологии, цифровой коворкинг-центр, кросс-платформа с цифровой индустрией, цифровой хаб-студия, хаб-ассоциация, хакатон, Интернет вещей.

Рис.: 1. Лит.: 19.

Постановка проблеми. Глобалізаційні процеси, які проходять у світі, уже неминучі, до того ж мають свої суттєві переваги. Такими ж неминучими $є$ i перетворення в сучасній економіці, коли на зміну класичній, яка правила світом сотні років, до законів якої пристосувалося все людство, приходить нова, 3 невідомими для основних гравців світу правилами та законами цифрова економіка. Поєднання цих “стихій” призводить до суттєвих змін у суспільному устрої, які треба враховувати, пристосовуватися до них і використовувати на користь сучасної економіки.

Класична економічна теорія, в основі якої лежали закони, постулати та категорії, що вважалися беззаперечними, як здавалося ще навіть 30-40 років тому, отримує нові напрями розвитку, які мають прийти і в теоретичну економіку 
під впливом процесів, які несе із собою глобалізація. Вплив сучасної цифрової економіки на процеси глобалізації очевидний, але виникає необхідність обгрунтувати його теоретично і дати логічне наукове пояснення цим явищам.

Аналіз останніх досліджень і публікації. За останні десятиліття в публікаціях економічного напряму все більше з'являється думок про те, що вплив на світову економіку інформаційних технологій призводить до змін у самій економіці, про це активно дискутують як вітчизняні вчені: Войнаренко М. П. [2], Гусева О. Ю. [7], Краус Н. М., Краус К. М. [6], Ляшенко В. І. [8], Малик І. П. [4], Норец Н. К. [5], Скоробогата Л. В. [2], Станкевич А. А. [5], так і вчені-економісти різних країн світу, зокрема Д. Тапскотт [3], Т. Левіт [9], Дж. Стігліц [10], Ерік С. Райнерт [11], У. Хус, Р. Аткінсон, С. Холройд Т. Месенбург та ін. Проте, питання безпосереднього впливу змін в економіці у бік цифровізації на глобалізаційні перетворення у світі обговорюються не достатньо, або на рівні інформатизації та впровадження ITтехнологій. Теоретичному обгрунтуванню цих взаємопов'язаних процесів не приділяється достатньої уваги, особливо тим новим напрямам, які або вивчені мало, або не вивчені зовсім.

Мета статті. Вивчення питань впливу цифровізації економіки в окремих галузях (економіках) та країнах на глобалізаційні процеси, що відбуваються в суспільстві, економіці світу, враховуючи зміни в теоретичній класичній економіці та зміни в сучасних категоріях і поняттях.

Виклад основного матеріалу. Вчені-економісти в Україні та світі, вивчаючи думку щодо розвитку цифрової економіки, по-різному сприймають не тільки власне цифрову економіку як науку, а й термін "цифрова економіка", тому виникають різні непорозуміння з приводу втілення самої ідеї “в життя”, адже різні тлумачення дефініції викликають різні вектори застосування ідеї, а це, відповідно, впливає і на сприйняття "цифрової економіки” в економічному співтоваристві як науки та на напрями їі розвитку у світі, тобто на глобалізаційні процеси загалом.

Як видно з попередніх наших досліджень [1] ще 10-20 років тому поняття цифрової економіки не домінувало в теоретичних дослідженнях як українських, так і зарубіжних вчених. Серед великої кількості термінів, що описували появу в економіці нових напрямів господарювання за допомогою Інтернет-технологій, власне Інтернету тощо виділимо декілька:

- “електронна економіка" (вперше цей термін використав Ніколас Негропонте ще в 1995 р., з часом він набув нової назви “цифрова економіка”). Станом на сьогодні категорія “електронна економіка" має дві складові: Інтернетекономіка (середовище для ведення електронного бізнесу) та "цифрова економіка", де відбувається виробництво, обмін, розподіл та споживання “електронного товару”, а розрахунки проводяться за допомогою електронних грошей [2];

- у тому ж 1995 р. почали використовувати і термін "цифрова економіка", зокрема, один із провідних вчених світу Дональд Тапскотт дав для неї таке 
визначення: цифрова економіка - економіка, що заснована на провідному застосуванні цифрових технологій [3]; а відомий американський програміст Ніколас Негропонте сформулював іï концепцію - у стислому вигляді вона звучить як “перехід від обробки атомів до обробки бітів”.

- неоекономіка (зародження і швидкий розвиток якої припадає на 20002015 рр.); трактується як постіндустріальна стадія розвитку економічної системи, фундаментальними теоретичними конструкціями якої $\epsilon$ інформаційна, інноваційна, економіка знань, цифрова, мережева економіка. Розмежування цих концепцій грунтується на виділенні ключових сфер та ресурсів економічного розвитку [2, с. 18];

- в Україні і світі виділяють різні назви нових видів понять економіки: “інформаційне суспільство”, “економіка знань”, “мережева економіка”, називаючи їх синонімами [4], або такими, що один можуть бути складовими іншого тощо.

На сьогодні в науковій економічній літературі термін “цифрова економіка" все більше стає домінантним і все частіше трапляється в економічній літературі як ключова категорія при визначенні сучасного економічного стану.

Велика когорта вчених сьогодення вважають, що цифрова економіка, хоч i увійшла в “щоденний вжиток", не забезпечила себе достатньою кількістю понять, категорій, не кажучи вже про нові економічні закони, за якими має жити людство в найближчі 50-100 років.

У технологічному аспекті цифрову економіку визначають чотири тренди: мобільні технології, бізнес-аналітика, хмарні обчислення і соціальні медіа; в глобальному плані - соціальні мережі, такі як Facebook, YouTube, Twitter, LinkedIn, Instagram та ін. За останні роки активного розвитку набули й такі Інтернет-залежні ринки, як туризм, ігри і кіберспорт, медіа та банківські послуги. Поступова цифровізація масового сегмента змінює характер on-line споживання. У сегменті туризму і подорожей яскравим є перехід від on-line бронювання квитків до повноцінного вибору, порівняння i оплати турів. У сегменті банківських послуг особисті кабінети замінюють стояння в черзі до каси банку 3 метою оплати комунальних платежів, поповнення телефону, оплати за кредити i т.д. [5, с. 176-177].

Деякі вчені, вивчаючи сьогоднішній стан діджиталізації та перспективи іiі розвитку в майбутньому, концентрують увагу на вивченні питань, спрямованих на розробку інструментів і механізмів роботи віртуальних цифрових коворкінгцентрів, крос-платформ із цифровою індустрією, цифрових хабів-студій, хабівасоціацій та хакатонів задля того, щоб на базі цього пізнання сформувати цифрову реальність в Україні. Адже віртуалізація дозволяє зменшити об'єм початкових капітальних витрат на розгортання необхідної цифрової інфраструктури шляхом використання "хмарних" технологій та програмновизначеної архітектури (з англ. "software-defined architecture") [6, c. 214].

Гусєва О. Ю. визначає цифрову економіку як економічну діяльність, яка відрізняється мережевою свідомістю та взаємозв'язком віртуальних технологій. 
Іншими словами - це економіка віртуальних світів [7].

Економічні зрушення та процеси, що відбуваються в сучасному світі, змінюються так швидко, що їх важко описати категоріями класичної економіки. Бурхливі зміни в політичних відносинах між країнами призводять до таких же змін у світовій економіці. Найвідчутніше це спостерігається в таких процесах як цифровізація та глобалізація, які надто тісно пов'язані між собою і мають приблизно однакові зміни векторів свого розвитку.

Важливим фактором розвитку як світової економіки, так і економіки окремих країн, всіх економічних процесів, що відбуваються в суспільстві $є$ вплив цифрової економіки на глобалізацію. Серед головних напрямів досліджень провідних науковців світу виділяються вплив цифрової економіки на ринок праці і форми її організації (У. Хус), зв'язок між інноваційною діяльністю та цифровою економікою (Р. Аткінсон), зв'язок глобалізації та цифровізації (С. Холройд). Саме на останньому ми хочемо сконцентрувати свої спостереження, тому що основні проблеми людства та економіки пов'язані саме 3 питаннями безробіття, бідності, а найважливіше - проблеми навколишнього середовища. Саме тут у планетарному масштабі вирішити, або, принаймні, скоротити негативні наслідки може застосування знань та використання реального надбання цифрової економіки.

Існують різні підходи до визначення інформаційної (цифрової) економіки. Одна із загальноприйнятих дефініцій, запропонована ще у 2001 році T. Месенбургом і використовується й досі в статистичних органах економічно розвинених країн. Згідно з цим підходом, до складу інформаційної (цифрової) економіки пропонується включати три основні компоненти:

інфраструктуру електронного бізнесу (обладнання, програмне забезпечення, телекомунікації, мережі, людський капітал тощо);

Інтернет); електронний бізнес (здійснення будь-яких бізнес процесів через Інтернеті) [8].

електронну комерцію (продаж або купівля товарів і послуг в

3 позицій класичної економічної теорії такий вибір компонентів не можна вважати випадковим. Обгрунтовані ще понад 150 років тому класиками політичної економії процеси "виробництва, розподілу, обміну та споживання" однозначно узгоджуються та корелюють з компонентами цифрової економіки. Електронний бізнес зумовлює цифровізацію виробництва. Електронна комерція, погоджуючи інтереси продавця і покупця, призводить до цифровізації обміну та розподілу. Одночасно відбувається розширення споживання цифрових продуктів. Масове придбання та використання мобільних додатків до смартфонів, які працюють під операційною системою Android чи iOS $\epsilon$ прикладом цифрового споживання. Якщо розглядати процес цифровізації 3 позиції поділу економіки на три сектори (первинний - сільське господарство і видобуток корисних копалин, вторинний - промислове виробництво, третинний - послуги), то принциповою відмінністю є не стільки збільшення частки 
третинного сектору або появи та розширення нового (цифрової економіки), а радикальне перетворення всіх трьох уже наявних секторів. 3 огляду на сучасні технологічні можливості й тенденції їхнього розвитку, може зникнути класичний поділ між зазначеними секторами. Наприклад, уже зараз технологічно можливо дистанційно в smart-режимі (онлайн) e-business infrastructure, ebusiness, e-commerce обробляти сільськогосподарські угіддя, збирати врожай, виробляти промислову продукцію, здійснювати медичні операції і надавати різноманітні послуги. Отже, відбувається цифровізація не окремих секторів економіки, а всієї економічної системи [8].

Термін «глобалізація» в сучасній економічній літературі $є$ таким, що не лише найчастіше вживається, але і є найбільш дискусійним. Підтверджуючи це, наведемо деякі його визначення класиками світової літератури. Уперше в науку його ввів Т. Левіт, визначивши як "феномен злиття ринків окремих продуктів, що виробляються великими багатонаціональними корпораціями” [9, с. 92-102]. Інший відомий учений, Нобелівський лауреат Дж. Стігліц вважав, що це усунення бар'єрів на шляху вільної торгівлі і більш тісна інтеграція національних економік [10]. Райнерт трактує поняття глобалізації як стрімку інтеграцію багатих і бідних країн стосовно торгівлі та інвестицій, що посилює злиття ринків завдяки транскордонному переміщенню товарів, капіталу, інформації, технологій та людей [11, с. 131]. Зазначимо, що той же Міжнародний валютний фонд не концентрує увагу на питаннях різного впливу глобалізації на розвиток багатих і бідних країн, здебільшого - багаті і надалі багатіють, бідні стають біднішими, але саме такими питаннями займаються багато вчених, щоб, використовуючи новітні знання, методи та інструменти впливу на економіку світу та окремих країн, прагнути до вирівнювання економічного розвитку окремих країн.

Розглянемо зазначені вище питання сучасних (у деяких випадках перспективних) інструментів i механізмів роботи віртуальних цифрових напрямів, у форматі їхнього зв'язку з глобальними економічними процесами. Новими напрямами цифрової індустрії можна вважати:

- коворкінг-центри, або коворкінг-простір. Це порівняно новий робочий простір для представників сучасних креативних та інноваційних професій, зокрема, Інтернет-працівники, які включають велику кількість різних сфер: програмування, дизайн тощо. Коворкінг у широкому значенні - підхід до організації праці людей з різною зайнятістю у загальному просторі; у вузькому подібний простір, колективний офіс [12]. Інше визначення - форма самоорганізації спільнот та вільних людей будь-яких професій, статусу, об'єднаних на одному просторі, щоб виконати якусь свою роботу [13]. Коворкінг сприяє розвитку стартап-культури (культура, яка будується або на основі нових інноваційних ідей або технологій, які щойно з'явилися), надаючи не тільки всю необхідну інфраструктуру для розвитку нового проєкту і створюючи певну творчу атмосферу, а й формуючи креативне співтовариство, члени якого можуть увійти в новий стартап-проєкт [14]. 
- крос-платформа із цифровою індустрією. Крос-платформа - віртуальна платформа для навчання і проведення WEB-конференцій (вебінарів). Це новий сервіс для навчання, який розбудовується із використанням цифрових технологій. В Україні, наприклад, за показниками доступності, вартості, розширених можливостей використовується для впровадження при навчанні крос-платформа WiZiQ. Цей сервіс дає можливість вчителям-предметникам створювати віртуальні класи і навчати учнів у режимі реального часу On-line. Учителі так само дістають можливість створювати профілі і наповнювати їх матеріалами, які пов'язані з їхньою діяльністю, і так само створювати невелику бібліотеку книжок і презентацій, [15] збільшувати потенціал спільної діяльності та започатковувати спільні проєкти не лише в межах мікро- чи мезорегіону, але і в країні загалом чи в декількох країнах. Такі крос-платформи сприяють обміну досвідом і налагодженню співпраці; в межах позашкільного навчання дають можливість покращити рівень комунікації між громадськими організаціями та представниками влади тощо.

- цифрові хаби-студії. Під хабом (з англ. "hub" - "центр", “маточина" (центральна частина обертової деталі якогось механізму), в загальному значенні, вбачаємо вузол будь-якої мережі.

Цифровим хабом можна вважати цифрову систему, котра включає власні цифрові проєкти та власну цифрову інфраструктуру і надає іншим структурам інформаційно-консалтингові, науково-технічні, науково-технологічні, інфраструктурні та виробничі сервіси з вирішення завдань трансферу технологій і комерціалізації об'єктів інноваційно-цифрової діяльності, цифровий хаб система взаємопов'язаних між собою Інтернет-проєктів, ядром якого є хабстудія (починаючи від хаб-школи-студії і закінчуючи хаб-кластером-студією), котра концентрує в собі вирішення глобальних, центральних завдань, проєктів тощо та залучає зацікавлені сторони до їхньої розробки та впровадження.

Принцип вирішення такого питання може базуватися, наприклад, на уже відомій платформі Інтернет речей.

Інтернет речей (IоT) - це не просто розумний будинок або розумне підприємство. Експерти прогнозують, що найближчим часом мільярди пристроїв будуть вирішувати найрізноманітніші завдання в різних галузях. Вони вже вирішують безліч завдань. На рис. 1 зображено типову функціональну схему роботи розумного пристрою з хмарою Azure, яку пропонує CISCO.

На схемі пристрій взаємодіє з ІоТ хабом. ІоТ хаб - це Центр інтернету речей. Він може як отримувати дані 3 пристроїв, так і відправляти їм повідомлення і команди [16].

Дослідниками з Оксфорда свого часу було виділено 5 головних атрибутів, які формують ідеальний інноваційний хаб [17]. Ми вважаємо, що основні його властивості відповідають і цифровому хабу:

1. Спільність. Хаби зазвичай підкреслюють, що вони лише слугують для зустрічей та об'єднання Інтернет-спільноти, і що без цієї спільноти вони були б нічого не варті. 


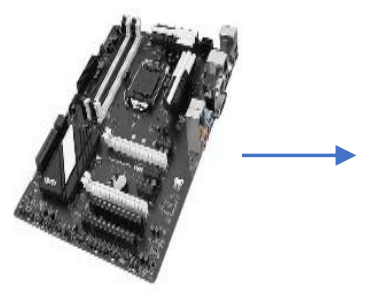

Пристрій

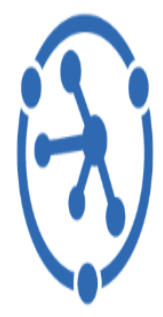

loT Hub
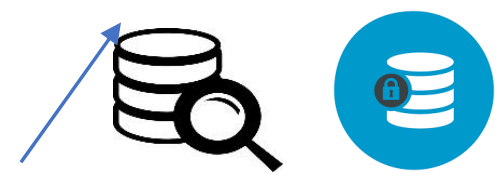

База даних

2. Самоорганізація і адаптивність. Хаби не повинні функціонувати зверху вниз; вони завжди виникають з «низової» ініціативи новаторів і підприємців. Менеджери хабів зазвичай вважають себе не стільки лідерами, скільки посередниками. У той час як донори і спонсори, як правило, необхідні для фінансування хабів, вони розглядаються швидше як підтримка. Їм не дозволено нав'язувати порядок денний, що не відповідав би потребам, які ставить товариство.

3. Не здійснювати інновації, а допомагати інноваторам. Хаби не є творцями або виконавцями інновацій (проєктів, стартапів, додатків тощо). Хаби можуть бути більш-менш вибагливими і жорсткими посередниками щодо виконавців, яких вони підтримують, але, врешті-решт, підприємці розглядаються як ті, хто реально впливає на світ.

4. Гетерогенне знання. Мабуть, найбільш цікавою властивістю хабів $є$ те, що вони прагнуть збирати однодумців, але в той же самий час об'єднувати людей 3 різним життєвим досвідом і знаннями. В основі лежить ідея, що стартапи потребують комплементарних складових (наприклад, креативного дизайну продукту і фінансування), а також, що інновація за своєю суттю спирається на нові й незвичайні поєднання знань.

5. Місцеві форпости вищої мети. Ще одним цікавим аспектом хабів є те, що вони підкреслюють адаптацію до місцевих умов, але в той же час мають тенденцію до самовизначення як частини глобального руху. Насправді коворкінг все частіше розглядається як глобальний рух. Він почав надавати ідеї і шаблони для проєктування хабів (які часто виявляються схожими у різних частинах світу) [17].

У вирішенні питань застосування цифрових хабів у сьогоднішньому глобалізованому світі важливо знаходити центр тяжіння - «хаб», якусь 
«центральну точку» досліджуваного об'єкта, економіки або інфраструктури галузі, держави, навколо якої все обертається. Створення такого хаба як центру виробництва конкурентоспроможної продукції послужить основою для групування навколо нього зони обслуговувальних організацій інфраструктурного призначення та їхньої подальшої інтеграції у кластер. Хаб можна розглядати як початок, відправну точку зародження майбутньої мережевої структури - кластера і появи нової форми організації взаємодії між економічними суб'єктами певного регіону. Найбільш інноваційно активна фірма, науково-дослідна організація чи вищий навчальний заклад можуть стати початковим центром, хабом, який об'єднується з визначеною кількістю ретельно відібраних, взаємозалежних за технологічним ланцюгом та зацікавлених в економічному симбіозі бізнес-партнерів.

- хаб-асоціація - зважаючи на визначення поняття «асоціації» (асоціація це договірне об'єднання, створене з метою постійної координації господарської діяльності підприємств, що об'єдналися, шляхом централізації однієї або кількох виробничих та управлінських функцій, розвитку спеціалізації і кооперації виробництва, організації спільних виробництв на основі об'єднання учасниками фінансових та матеріальних ресурсів для задоволення переважно господарських потреб учасників асоціації. У статуті асоціації повинно бути зазначено, що вона $\epsilon$ господарською асоціацією. Асоціація не має права втручатися у господарську діяльність підприємств - учасників асоціації. За рішенням учасників асоціація може бути уповноважена представляти їхні інтереси у відносинах 3 органами влади, іншими підприємствами та організаціями [18]), припустимо, що це таке ж договірне об'єднання ключових гравців Інтернет-спільноти для координації спільних дій з одним хаб-центром, який координує діяльність передусім фірмвиробників товару, фірм-продавців та фірм, що надають інфраструктурні послуги. Ключовою відмінністю хаб-асоціації має бути невтручання в діяльність фірм-учасників, зокрема, у фінансову. Створення таких хаб-асоціацій може бути корисним для будь-яких за розміром суб'єктів у період становлення «правил гри» під час формування надструктур різного спрямування в процесі всепоглинаючої глобалізації.

- хакатон - це (англ. hackathon, від hack (див. хакер) та marathon - марафон) - форум, під час якого різні спеціалісти в галузі розробки програмного забезпечення інтенсивно і згуртовано разом працюють над розв'язанням якоїсь проблеми або створенням нового додатку чи сервісу. Зазвичай хакатони тривають від одного дня до тижня. Деякі хакатони призначені для освітніх або соціальних цілей, але часто завданням хакатона $є$ створення повноцінного програмного забезпечення. Кожний хакатон сфокусовано на певній галузі, наприклад, мови програмування, операційні системи, додатки, програмний інтерфейс (API) [19]. У такому значенні цей термін, ми вважаємо, найкраще відповідає запиту цифрової економіки.

Запропоноване нами тлумачення означених термінів дасть можливість використовувати їх, якщо не в такому варіанті, то хоча б у наближеному до 
певного напряму досліджень.

Отже, використання визначених нами інструментів та механізмів розвитку віртуалізації в глобальному вимірі дозволить скоротити передусім початкові капітальні витрати на розгортання необхідної цифрової інфраструктури, адже процес ії становлення в усьому світі майже однаковий, вимагає розробки, а потім використання одних і тих же методів, способів, знань, а завдяки впровадженню "хмарних" технологій та програмно-визначеної архітектури ці витрати значно скорочуються.

Вивчаючи вплив цифрової економіки на глобалізаційні процеси, які відбуваються у світовому просторі, ми дійшли думки, що сучасна Україна має прийняти в цьому процесі безпосередню участь і зробити свій внесок у розвиток зазначеного процесу. Маючи велику кількість підготовлених у країні ITспеціалістів, які працюють як в Україні, так і в усьому світі (ми також розуміємо, що основні базові знання у них майже однакові, більше того, вони базуються на одній-двох школах, започаткованих ще 30-40 років тому), використовуючи такий «колективний розум», можна створити світову мережу IT-спеціалістівукраїнців для впровадження основних, передусім, бізнес-ідей i залучення грошових надходжень можливо спочатку в цифровий хаб "Україна та ITукраїнці", а потім і для підтримки своєї держави.

IT-українці можуть не лише поставляти IT-рішення іншим країнам, але й започаткувати якнайшвидше впровадження цифрової економіки в країні. Це має бути не тільки «виробництво», а й «споживання» IT-продукції у своїй країні.

Чому це так важливо сьогодні для України? Тому що так звана третя хвиля глобалізації, яку називають інклюзивною, означає, що завдяки розвитку цифрової економіки малий та середній бізнес (МСБ) отримав недоступну раніше можливість стати глобальним, вплив МСБ на світову економіку стає все більш відчутним. Якщо першу хвилю глобалізації у XIX та на початку XX століття контролювали великі держави (в основному їхні правителі), другу транснаціональні корпорації, то третя хвиля відбуватиметься завдяки малим компаніям. Всесвітньо відомою стала концепція засновника компанії Alibaba Джека Ма на форумі у Давосі: «30-30-30»: протягом наступних 30 років світ змінюватимуть ті, кому сьогодні 30, та компанії, в яких працює 30 співробітників.

Україна змушена та “приречена" скористатися такою можливістю, адже умови, в яких вона сьогодні опинилася, є надзвичайно сприятливі саме для початку розвитку за таким сценарієм і зовсім не сприяють швидкому відновленню розвитку за класичним сценарієм: швидке відновлення промисловості, транспорту і навіть сільського господарства як складової АПК. Надзвичайного значення набуває такий напрям розвитку сучасної економіки при наближенні чергової хвилі економічної світової кризи, яка (за передбаченнями провідних економістів світу та прогнозами найвпливовіших університетів) має прийти взимку 2019-2020 року.

Висновки. Економіка світу розвивається швидкими темпами, а отже цей 
розвиток має свої наслідки. Найважливішими з них є перехід від класичної до цифрової економіки і вплив ії̈ на процеси глобалізації, що викликані змінами у самій економіці. Класична економіка поступається своїми постулатами не тільки в практичній (прикладній) економіці, а й у теоретичній. На зміну старим законам, категоріям, поняттям, інструментарію приходять нові, які вимагають свого теоретичного обгрунтування та осмислення. Ми зосередилися на нових та таких, що стають перспективними, поняттях - цифровий коворкінг-центр, кросплатформа із цифровою індустрією, цифровий хаб-студія, хаб-асоціація, хакатон, Інтернет речей, яким дали своє визначення або запропонували для використання найбільш прийнятні, на нашу думку, що вже використовуються в науковій літературі.

Проведені дослідження дають змогу стверджувати: глобальні зміни в сучасній економіці суттєво впливають на глобалізаційні процеси у світі. Україна, маючи унікальний потенціал IT-спеціалістів, має використати його на користь розвитку як світової, так і своєї економіки, особливо в переддень нової хвилі економічної кризи, яка, за передбаченням провідних учених світу, матиме глобальний характер.

\section{Список використаних джерел}

1. Коляденко С. В. Цифрова економіка: передумови та етапи становлення в Україні і у світі. Економіка, фінанси, менеджмент: актуальні питання науки $i$ практики. 2016. № 6. С. 105-112.

2. Войнаренко М. П., Скоробогата Л. В. Мережеві інструменти капіталізації інформаційно-інтелектуального потенціалу та інновацій. Вісник Хмельницького національного університету. Економічні науки. 2015. № 3. Т. 3. C. $18-24$.

3. Tapscott, Donald. 1996. The Digital Economy. McGraw-Hill.

4. Малик І. П. Тенденції розвитку інформаційної економіки в Україні. Вісник Східноєвропейського університету економіки $і$ менеджменту. 2013. Випуск 1 (14). С. 25-34.

5. Норец Н. К., Станкевич А. А. Цифровая экономика : состояние и перспективы развития. Инновационные кластеры в цифровой экономике: теория и практика : труды научно-практической конференции с международным участием 17-22 мая 2017 года / под ред. д-ра экон. наук, проф. А. В. Бабкина. Санкт-Петербург : Изд-во Политехн. ун-та, 2017. С. 173-179.

6. Краус Н. М., Краус К. М. Цифровізація в умовах інституційної трансформації економіки: базові складові та інструменти цифрових технологій. Бізнес та інтелектуальний капітал. Інтелект XXI. № 1. 2018. С. 211-214.

7. Гусєва О. Ю. Напрями реалізації концепції цифрової економіки України. Економіка. Менеджмент. Бізнес. № 2 (24), 2018. С. 97-102.

8. Ляшенко В.I. Цифрова модернізація економіки України як можливість проривного розвитку: монографія / В.І. Ляшенко, О.С. Вишневський; НАН України, Ін-т економіки пром-сті. Київ, 2018. 252 с. 

1983.

9. Levitt T. The globalozationof Markets. Harvard Businass Review. May-June

10. Joseph E. Stiglitz. Globalization and its Discontents. New York-London: W.W. Norton \& Company. 2002.

11. Райнерт Ерік С. Як багаті країни забагатіли... і чому бідні країни лишаються бідними. Пер. 3 англ. Переклад з англійської Петра Терещука. Київ: Темпора, 2015. 444 c.

12. Коворкинг: большие перспективы маленького формата. URL : //www.arendator.ru/articles/5/art/63751/

13. История коворкинга. URL http://www.tikitoki.com/timeline/entry/156192/The-History-Of-CoworkingPresentedBy Deskmag\#vars !date= 1995-05-28_08:55:49

14. Снігур X. Коворкінг: переваги та недоліки а організації робочих місць. Вісник Тернопільського національного економічного університету. 2017. № 4. С. $\sim 117-124$. навчальне середовище вчителя загальноосвітнього навчального закладу. URL : http://lib.iitta.gov.ua/197/1/statja-4.pdf

16.

Центр

Интернета вещей

Azure.

URL: https://azure.microsoft.com/ruru/services/iot-hub/

17. Оксфордський інститут Інтернету, Оксфордський університет (2014р.), "Чим $\epsilon$ в принципі технологічний інноваційний хаб”, URL : http://cii.oii.ox.ac.uk/2014/09/16/what-is-a-tech-innovation-hub-anyway

18. Вікіпедія. URL : https://zakon.rada.gov.ua/rada/term/1207

19. Вікіпедія. URLttps:uk.wikipedia.org/wiki/\%\%A5\%D0\%B0\%D0\%BA \%D0\%B0\%D 1\%82\%D0\%BE\%D0\%BD

\section{References}

1. Koliadenko, S. V. (2016). Tsyfrova ekonomika: peredumovy ta etapy stanovlennia v Ukraini i u sviti. [The digital economy: preconditions and stages of formation in Ukraine and in the world.]. Ekonomika. Finansy. Menedzhment: aktualni pytannia nauky $i$ praktyky. Retrieved from file:///C:/Users/admin/Downloads/efmapnp_2016_6_11\%20(1).pdf [in Ukrainian].

2. Voinarenko, M. P., Skorobohata, L. V. (2015). Merezhevi instrumenty kapitalizatsii informatsiino-intelektualnoho potentsialu ta innovatsii. [Networking tools for capitalization of information and intellectual potential and innovation]. Visnyk Khmelnytskoho natsionalnoho universytetu. Ekonomichni nauky, 3. 18-24 [in Ukrainian].

3. Tapscott, Donald. 1996. The Digital Economy. McGraw-Hill.

4. Malyk, I. P. (2013). Tendentsii rozvytku informatsiinoi ekonomiky v Ukraini. [Trends in Information Economy Development in Ukraine]. Visnyk Skhidnoievropeiskoho universytetu ekonomiky i menedzhmentu, 1 (14). 25-34 [in Ukrainian]. 
5. Norets, N. K., Stankevich, A. A. (2017). Tsifrovaya ekonomika : sostoyanie $i$ perspektivyi razvitiya. [Digital economy: state and development prospects]. Innovatsionnyie klasteryi $\mathrm{v}$ tsifrovoy ekonomike: teoriya i praktika : trudyi nauchnoprakticheskoy konferentsii s mezhdunarodnyim uchastiem 17-22.05.2017. SPb. : Izdvo Politehn. un-ta, 173-179 [in Ukrainian].

6. Kraus, N. M. \& Kraus, K. M. (2018). Tsyfrovizatsiia v umovakh instytutsiinoi transformatsii ekonomiky: bakhovi skladovi ta instrumenty tsyfrovykh tekhnolohii. [Digitalization in the Conditions of Institutional Transformation of the Economy: Highlights and Instruments of Digital Technologies]. Biznes ta intelektualnyi kapital. Intelekt KhKhI. 1, 211-214 [in Ukrainian].

7. Husieva, O. Yu. (2018). Napriamy realizatsii kontseptsii tsyfrovoi ekonomiky Ukrainy. [Directions of realization of the concept of digital economy of Ukraine]. Ekonomika. Menedzhment. Biznes. № 2 (24), 97-102 [in Ukrainian].

8. Liashenko, V.I., Vyshnevskyi; O.S. (2018). Tsyfrova modernizatsiia ekonomiky Ukrainy yak mozhlyvist proryvnoho rozvytku: monohrafiia [Digital modernization of the Ukrainian economy as an opportunity for breakthrough development: monograph]. NAN Ukrainy, In-t ekonomiky prom-sti. Kyiv, 252 [in Ukrainian].

9. Levitt T. The globalozationof Markets. Harvard Businass Review. May-June 1983.

10. Joseph, E. (2002). Stiglitz. Globalization and its Discontents. New YorkLondon: W.W. Norton \& Company.

11. Rainert Erik S. (2015). Yak bahati krainy zabahatily i chomu bidni krainy lyshaiutsia bidnymy. [How rich countries got rich ... and why poor countries remain poor]. Per. $\mathrm{z}$ anhl. Pereklad z anhliiskoi Petra Tereshchuka. Kyiv: Tempora, 444 [in Ukrainian].

12. Kovorkynh: bolshye perspektyvы malenkoho formata. [Coworking: Big prospects for small format]. Retrieved from http://www.arendator.ru/articles/5/art/63 $751 /$

13. Istoriya kovorkinga. [History of coworking] Retrieved from http://www.tikitoki.com/timeline/entry/156192/The-History-Of-CoworkingPresentedBy Deskmag\#vars !date= 1995-05-28_08:55:49

14. Snihur, Kh. (2017). Kovorkinh: perevahy ta nedoliky a orhanizatsii robochykh mists [Coworking: the advantages and disadvantages of organizing jobs]. Visnyk Ternopilskoho natsionalnoho ekonomichnoho universytetu. 4, 117-124 [in Ukrainian].

15. Lytvynova, S. H. Virtualnyi klas yak kompiuterno-oriientovne navchalne seredovyshche vchytelia zahalnoosvitnoho navchalnoho zakladu [Virtual Classroom as a Computer-Oriented Educational Environment for a Primary School Teacher]. Retrieved from http://lib.iitta.gov.ua/197/1/statja-4.pdf

16. Tsentr Interneta veschey Azure [Azure Internet Hub]. Retrieved from https://azure.microsoft.com/ruru/services/iot-hub/

17. Oksfordskyi instytut Internetu, Oksfordskyi universytet (2014 r.), "Chym ye 
$v$ pryntsypi tekhnolohichnyi innovatsiinyi khab" [Oxford Institute of the Internet, University of Oxford (2014), "What is a technological innovation hub in principle"] Retrieved from http://cii.oii.ox.ac.uk/2014/09/16/what-is-a-tech-innovation-hubanyway $/ 1207$

18. Vikipediia [Wikipedia]. Retrieved from https://zakon.rada.gov.ua/rada/term

19. Vikipediia [Wikipedia]. Retrieved from https: //uk.wikipedia.org/wiki/\%D0 $\%$ A5\%D0\%B0\%D0\%BA\%D0\%B0\%D1\%82\%D0\%BE\%D0\%BD

\section{Відомості про автора}

КОЛЯДЕНКО Світлана Василівна - доктор економічних наук, професор, професор кафедри комп'ютерних наук та економічної кібернетики, Вінницький національний аграрний університет (21008, м. Вінниця, вул. Сонячна, 3, e-mail: kolyadenkosv@ukr.net).

KOLIADENKO Svitlana - doctor of Economic Sciences, Professor of the department of computer science and economic cybernetics. Vinnitsa national agrarian university (21008, Vinnitsa, Soniachna st. 3, e-mail: kolyadenkosv@ukr.net).

КОЛЯДЕНКО Светлана Васильевна - доктор экономических наук, профессор, профессор кафедры компютерных наук и экономической кибернетики, Винницкий национальный аграрный университет (21008, г. Винница, ул. Солнечная, 3, e-mail: kolyadenkosv@ukr.net).

УДК: 33.334

DOI: $10.37128 / 2411-4413-2020-2-6$

ІНФОРМАЦІЙНІ

ТЕХНОЛОГІї У

ПІДПРИЕМНИЦЬКИХ

СТРУКТУРАХ
БЕРЕЗЮК С.В., кандидат економічних наук, доцент кафедри адміністративного менеджменту та альтернативних джерел енергіï, Вінницький національний аграрний університет (м. Вінниця)

ОННЩЕНКО М.Л., кандидат економічних наук, доцент кафедри управління, Сумський державний університет (м. Суми)

У статті розглянуто зарубіжний та вітчизняний досвід розвитку IT-ринку з огляду на інформатизаиію суспільства як одну із найбільш характерних особливостей сучасного 